\title{
IMPLEMENTASI MODEL PEMBELAJARAN KOOPERATIF TIPE PENGALIRAN PROGRAM IMAS (IMAGE STREAMING) DALAM PENINGKATAN PEMBELAJARAN MENULIS KARANGAN NARATIF PADA SISWAKELAS X SMA NEGERI I POLUT KABUPATEN TAKALAR
}

\author{
Nur Ahmadi ${ }^{1}$ Yuliana $^{2}$ \\ Fakultas Keguruan dan Ilmu Pendidikan, Universitas Muhammadiyah Makassar \\ ahmad.nur@gmail.com \\ Fakultas Keguruan dan Ilmu Pendidikan, Universitas Muhammadiyah Makassar \\ yuli.yuli@gmail.com
}

\begin{abstract}
This research aimed to improve the ability to write narrative through IMAS learning model (image streaming) Grade Students of SMA X.5 I Polut KabupatenTakalar totaling 29 students. Data collection technique used a model observation, documentation and testing. The data analysis technique used the model descriptive analysis to measure the ability to write the test results of the study (1 time giving the test) every cycle by using the distribution frequency of and the percentage of the first is that there is an increase in the quality of the learning process to write a paragraph of narrative once held a class action learning model IMAS ( Image Streaming). The results showed an increase in student learning outcomes. The average score of the first cycle of 69.59 with classical completeness $16(55.17 \%)$ completed, are in the low category and increased in the second cycle 83.13 with classical completeness 29 (100\%) completed. This is supported by the increase in activity and creativity of the students in the learning process of the first cycle increased in the second cycle. This means the application of learning models IMAS (Iamge Stream) in learning Indonesian can improve the ability to write a narrative paragraph X.5 grade students of SMA I Polut Takalar.
\end{abstract}

Keywords: Writing paragraphs of narrative, learning model IMAS (Image Streaming)

\begin{abstract}
Abstrak
Penelitian tindakan kelas ini bertujuan untuk meningkatkan kemampuan menulis naratif melalui model pembelajaran IMAS (image streaming) pada siswa kelas X.5 SMA Negeri I Polut Kabupaten Takalar yang berjumlah 29 siswa. Teknik Pengumpulan data yang digunakan adalah model observasi, dokumentasi dan tes. Teknik analisis data yang digunakan adalah model analisis deskriptif untuk mengukur kemampuan menulis hasil tes penelitian (1 kali pemberian tes) setiap siklus dengan menggunakan distribusi frekuansi dan persentase yang pertama bahwa ada peningkatan kualitas proses pembelajaran menulis paragraf naratif setelah diadakan tindakan kelas dengan model pembelajaran IMAS (Image Streaming). Hasil penelitian menunjukkan adanya peningkatan hasil belajar siswa. Skor rata-rata siklus I 69,59 dengan ketuntasan klasikal 16 orang $(55,17 \%)$ tuntas, berada pada kategori rendah dan meningkat pada siklus II 83,13 dengan ketuntasan klasikal 29 orang (100\%) tuntas. Hal ini didukung oleh peningkatan keaktifan dan kreatifitas siswa dalam proses belajar mengajar dari siklus I meningkat pada siklus II. Ini berarti penerapan model pembelajaran IMAS (Iamge Streaming) dalam pembelajaran Bahasa Indonesia dapat meningkatkan kemampuan menulis paragraf naratif siswa kelas X.5 SMA Negeri I Polut Kabupaten Takalar.
\end{abstract}

\section{Kata kunci: Menulis paragraf naratif, model pembelajaran IMAS (Image Streaming)}

\section{Pendahuluan}

Bahasa Indonesia sebagai alat komunikasi bagi manusia, bahasa Indonesia juga berfungsi sebagai bahasa pengantar pembelajaran dalam dunia pendidikan dan sekaligus sebagai bahan materi dalam proses belajar-mengajar anak didik di sekolah. Pembelajaran bahasa Indonesia di sekolah merupakan salah satu upaya pengembangan dan pelastarian bahasa Indonesia. Bahasa 
Indonesia harus diajarkan pada semua jenjang pendidikan mulai tingkat taman kanak-kanak sampai perguruan tinggi.

Bahasa Indonesia sebagai bahasa pengantar dalam proses belajar mengajar, mempunyai fungsi 1) sarana pembinaan persatuan dan kesatuan bangsa, 2) sarana peningkatan dan keterampilan berbahasa Indonesia dalam rangka pelestarian dan pengembangan budaya, 3) sarana peningkatan pengetahuan dan keterampilan berbahasa Indonesia untuk meraih pengembangan ilmu pengetahuan teknologi dan seni, 4) sarana penyebarluasan penggunaan bahasa Indonesia yang baik untuk berbagai keperluan menyangkut berbagai masalah, 5) sarana pengembangan penalaran. Mustakim (dalam Nismawati, 2011: 1).

Dari uraian tersebut di atas salah satu cara yang harus dikembangkan dalam peningkatan pengetahuan dan keterampilan berbahasa adalah mengoptimalkan pembelajaran keterampilan berbahasa di kalangan siswa SMA, salah satu diantara keterampilan tersebut yaitu keterampilan menulis yang oleh penulis akan memfokuskan pada keterampilan kemampuan menulis karangan naratif.

Siswa juga hanya mengembangkan hasil pengamatan berdasarkan indera penglihatan saja. Siswa kurang memanfaatkan indera yang lain seperti pendengaran, ataupun perabaan untuk mengembangkan karangan naratif sehingga pembaca kurang dapat melihat dan merasakan apa yang ditulis siswa melalui panca inderanya. Selain itu, siswa belum mampu menggunakan ejaan dengan tepat. Masih banyak terdapat kesalahan penulisan ejaan dalam karangan naratif siswa, baik dalam penggunaan kata depan, imbuhan, maupun tanda baca. Seseorang dengan menulis dapat mengungkapkan pikiran dan gagasan untuk mencapai maksud dan tujuannya. Tarigan (1982: 21) mengatakan bahwa menulis ialah menurunkan atau melukiskan lambang-lambang grafik yang menggambarkan suatu bahasa yang dipahami oleh seseorang, sehingga orang-orang lain dapat membaca lambang-lambang grafik tersebut, kalau mereka memahami bahasa dan gambaran tersebut.

Menurut Akhadiah, dkk. (1988: 2) menulis adalah kemampuan kompleks yang menuntut sejumlah pengetahuan dan keterampilan. Dengan menulis, penulis terdorong untuk terus belajar secara aktif. Penulis menjadi penemu sekaligus pemecah masalah bukan sekadar menjadi penyadap informasi dari orang lain.Menulis merupakan kemampuan berbahasa yang produktif dalam menuangkan pikiran dan gagasan, serta menyusun informasi dalam bentuk karangan. Kegiatan menulis bisa berasal dari membaca atau menyimak suatu informasi. Selain itu, menulis dapat juga berasal dari berbagai kejadian-kejadian yang dialami oleh penulis sendiri maupun orang lain. Tulisan merupakan salah satu media yang digunakan untuk mengungkapkan pikiran, gagasan, perasaan, atau kemauan seoang penulis.

Sehubungan dengan hal ini seorang penulis yang mengatakan bahwa "menulis dipergunakan oleh orang terpelajar untuk mencatat/merekam, meyakinkan, melaporkan/memberitahukan, dan mempengaruhi; dan maksud serta tujuan seperti itu hanya dapat menyusun pikirannya dan mengutarakannya dengan jelas, kejelasan ini tergantung pada pikiran, organisasi, pemakaian kata-kata, dan struktur kalimat". Morsey (dalam Tarigan, 1982: 4).

Menulis adalah suatu bentuk berpikir, tetapi justru berpikir bagi membaca tertentu dan bagi waktu tertentu. Salah satu dari tugastugas terpenting sang penulis sebagai penulis adalah menguasai prinsip-prinsip menulis 
dan berpikir, yang akan menolongnya mencapai maksud dan tujuannya. Yang paling penting diantara prinsip-prinsip yang dimaksudkan itu adalah penemuan, susunan, dan gaya. Secara singkat: belajar menulis adalah belajar berpikir dalam/dengan cara tertentu. D'Angelo (dalam Tarigan, 1982:22).

Munirah (2007: 2) mengungkapkan bahwa menulis merupakan suatu bentuk komunikasi yang tidak langsung untuk menyampaikan gagasan penulis kepada pembaca dengan menggunakan media bahasa yang dilengkapi dengan unsur Suprasegmental.

Akhadiah, dkk (dalam Munirah 2007: 1) menyatakan bahwa menulis merupakan suatu bentuk komunikasi. Menulis merupakan suatu proses pemikiran yang dimulai dengan pemikiran tentang gagasan yang akan disampaikan, menulis merupakan bentuk komunikasi yang berbeda dengan bercakap-cakap; dalam tulisan tidak terdapat intonasi, ekspresi wajah, gerakan fisik, serta yang tidak menyertai percakap: menulis merupakan bentuk komunikasi yang perlu dilengkapi dengan tanda-tanda penjelas, aturan, ejaan serta tanda baca, dan menulis kepada khalayak pembca yang dibatasi oleh jarak, tempat dan waktu.

Berdasarkan pendapat beberapa ahli di atas, dapat disimpulkan bahwa menulis adalah proses menuangkan pikiran, gagasan, perasaan, atau kemauan untuk dibaca dan dimengerti oleh orang lain dengan menggunakan wahana bahasa tulis berdasarkan tataan tertentu sesuai dengan kaidah bahasa yang digunakan penulis.

Berdasarkan dari segi sifat isinya, dikenal lima jenis menulis menurut A. Rahman Rahim dan Thamrin Paelori (2013: 91) menyatakan bahwa terbagi atas lima jenis, yaitu sebagai berikut;

a. Naratif adalah rangkaian tuturan yang menceritakan atau menyajikan suatu hal kejadian melalui tokoh pelau (I orang atau III) dengan maksud memperluas pengetahuan pendengar atau pembaca. Pegorganiasian wacana ini mengutamakan pada urutan cerita berdasarkan waktu atau berdasarkan kronologisnya.

b. Deskriptif berupa rangkaian tuturan yang memaparkan sesuatu atau melukiskan sesuatu baik berdasarkan pengalaman atau pengetahuan penuturnya.

c. Eksposisi merupakan rangkaian tuturan yang bersifat memaparkan suatu pokok pikiran. Tujuan pokok yang ingin dicapai pada wacana ini tercapainya tingkat pemahaman akan sesuatu itu supaya lebih jelas, mendalam, dan lebih dari sekedar sebuah pernyataan yang bersifat global atau umum.

d. Argumentasiadalah tuturan yang memberikan alasan dengan contoh dan bukti serta meyakinkan, sehingga orang akan terpengaruh dan membenarka pendapat, gagasan, sikap dan keyakinan kita, akhirnya orang lain akan berbuat sesuai dengan kehendak itu.

e. Persuasif adalah membujuk, mendorong, meyakinkan. Wacana persuasif adalah wacana yang disusun dengan tujuan mengajak, mendorong, membujuk, mempengaruhi para pembaca agar mau mengikuti kemauan si penulis.

Menulis digunakan untuk orang terpelajar untuk berbagai tujuan seperti mencatat, merekam, meyakinkan, memberitahu dan mempengaruhi.

Hugo (dalam Munirah 2007: 6) merangkum dengan tujuan penulisan sebagai berikut; 1) Tujuan penugasan, 2) Tujuan altruistik, 3) Tujuan persuasif, 4) Tujuan penerangan, 5) Tujuan pernyataan diri, 6) Tujuan kretif, 7) Tujuan pemecahan masalah. Tujuan pembelajaran menulis yang ditekankan oleh Bernard Percy (dalam Gie, 2002: 21), mengemukakan tidak kurang dari 
enam manfaat kegiatan mengarang, yakni sebagai berikut:

a. Mengarang sebagai suatu sarana untuk pengungkapan diri (a toolfor self expression).

b. Mengarang sebagai suatu sarana untuk pemahaman (a tool for understanding).

c. Mengarang sebagai suatu sarana untuk meningkatkan sarana untuk membantu mengembangkan kepuasan pribadi, kebanggan, dan suatu perasaan harga diri (a tool to help to developing personal satisfaction, pride, and a feeling of selfworth).

d. Mengarang sebagai suatu sarana untuk meningkatkan kesadaran dan penerapan terhadap lingkungan sekeliling seseorang (a tool for increasing awareness and perception of one's environment).

e. mengarang sebagai suatu sarana untuk keterlibatan secara bersemangat dan bukannya penerimaan yang pasrah (a tool for active involvement, not passive acceptance).

f. Mengarang sebagai suatu sarana untuk mengembangkan suatu pemahaman dan kemampuan tentang menggunakan bahasa (a tool for developing an understanding of and ability to use the language).

Akhadiah, dkk. (1988:

membedakan proses penulisan menjadi tiga tahapan, yaitu (1) tahap prapenulisan, (2) tahap penulisan, dan (3) tahap revisi. Akhadiah, dkk. (1988: 3), dalam tahap prapenuliasan ditentukan hal-hal pokok yang akan mengarahkan penulis dalam seluruh kegiatan penulisan itu dalam tahap penulisan dilakukan apa yang telah ditentukan, yaitu mengembangkan gagasan dalam kalimatkalimat, satuan paragraf, bab atau bagian, sehingga selesailah buram (draf) yang pertama; dan dalam tahap revisi, yang dilakukan ialah membaca dan menilai kembali apa yang sudah ditulis, memperbaiki, mengubah, bahkan jika perlu memperluas tulisan.

Taniredja, dkk. (2013: 101) menjelaskan terdapat enam langkah utama di dalam pembelajaran kooperatif, yaitu:

1. Menyampaikan Tujuan dan Memotivasi Siswa

Pelajaran dimulai dengan guru menyampaikan tujuan pelajaran yang ingin dicapai pada pelajaran tersebut dan memotivasi siswa untuk belajar.

2. Menyajikan Informasi

Guru menyajikan informasi kepada siswa dengan jalan demonstrasi atau lewat bahan bacaan.

3. Mengorganisasikan Siswa ke Dalam

Kelompok-kelompok Belajar

Guru menjelaskan kepada siswa bagaimana caranya membentuk kelompok belajar dan membantu setiap kelompok agar melakukan transisi secara efisien.

4. Membimbing Kelompok Bekerja dan

Belajar

Guru membibing kelompok-kelompok belajar pada saat mereka mengerjakan tugas.

5. Evaluasi

Guru mengevaluasi hasil belajar tentang materi yang telah dipelajari atau masingmasing kelompok mempresentasikan hasil belajarnya.

6. Memberikan Penghargaan

Guru mencari cara-cara untuk menghargai baik upaya maupun hasil belajar individu dan kelompok.

Pembelajaran kooperatif dapat mengembangkan hubungan antar kelompok, penerimaan terhadap teman sekelas yang lemah dalam bidang akademik. Oleh karena itu, siswa yang lemah bidang akademiknya dapat memberikan sumbangsi terhadap timnya. Pembelajaran kooperatif ini dapat pula menumbuhkan kesadaran para siswa perlu belajar untuk berpikir, menyelesaikan 
masalah, mengintegrasikan masalah, serta mengaplikasikan kemampuan dan pengetahuan mereka.

\section{Tipe Pengaliran Program IMAS (Image Streaming)

Metode Image Streaming
(mengalirkan bayangan) merupakan kegiatan membiarkan bayangan-bayangan hadir dan muncul di hadapan mata pikiran, tetapi tidak memutuskan secara sadar isi bayanganbayangan tersebut. Sementara melihat bayangan-bayangan itu, deskripsikan dengan cermat kepada fokus eksternal (alat perekam atau Pendengar) isi bayangan-bayangan tersebut dengan detail (Wenger, 2004: 308).

Wenger (2004: 294) mengungkapkan, metode Image Streaming merupakan salah satu cara mudah untuk mendapatkan kembali memori masa kanak-kanak yang tersimpan dalam pikiran.

Ada beberapa langkah yang perlu diperhatikan dalam metode Image

\section{Streaming:}

1. Biarkan yang lebih halus dan dalam memperlihatkan dirinya. Jangan langsung memutuskan dengan sadar apa yang ingin di lihat dan kemudian anda gambarkan. Hubungkan dengan bayangan-bayangan yang benar-benar hadir dihadapan peserta.

2. Tutup mata untuk melihat yang lebih bebas.

3. Apapun kesan yang ditemukan, betapa remeh, sederhana, tak berhubungan bahkan warna atau garis yang tampaknya tak berarti tuliskan semua.

4. Deskripsikan bayangan itu dengan lantang kepada fokus eksternal (selain atau di luar diri peserta). Pendengar langsung adalah yang terbaik; alat perekam juga baik.

5. Deskripsikan dengan cepat dan mengalir, dengan detail indrawi ynag kaya, berkesinambungan, sekalipun hanya sekadar sekilas dan ringkas. Hal ini memaksa lebih banyak bayangan bebas hadir dan bermunculan.

6. Tanpa menghiraukan taktik yang digunakan untuk mendapatkan beberapa jenis kesan dan suatu aliran deskriptif yang terjadi: perhatikan kapan pemandangan berubah dan bayanganbayangan lain hadir dan muncul, dan deskripsikan semua.

Dalam Bayond Teaching and Learning, Wenger (2004:330-333) menjelaskan manfaat dan kegunaan Image Streaming, yaitu:

1. Dapat mempertajam seluruh keterampilan berpikir visual dan membantu menggambarkan visualisasi. Dengan kata lain metode mengalirkan bayangan dapat meningkatkan kemampuan otak.

2. Dalam meningkatkan kemampuan otak, metode ini menarik bayangan dan kesan dari suatu rentang yang luas di dalam otak dan mengekspresikan secara eksternal dengan cara mendeskripsikannya.

3. Dapat memperluas area otak agar dapat "on-line" (nyambung) dengan kesadaran.

Pengaliran bayangan melibatkan serta melatih area-area otak yang terpisah: lobus temporal kiri (verbal) melakukan pendeskripsian dengan kata-kata, dan pusat mayoritas kesadarankita. Masih banyak wilayah otak lainnya yang dilibatkan untuk mengubah pemahaman menjadi bayanganbayangan visual yang menjelaskan pemahaman atau hubungan data itu. Termasuk lobus temporal kanan, yang bertugas khusus "merasakan" segala sesuatu serta mengapresiasi keindahan.

Pemilihan model pembelajaran yang tidak tepat dapat menurunkan motivasi dan minat belajar siswa sehingga tujuan pembelajarantidak tercapai secra optimal. Apabila dikaji lebih lanjut berdasarkan teori yang telah da maka salah satu alternatif peningkatan hasil belajar siswa di sekolah 
adalah penggunaan model pembelajaran kooperstif tipe pengaliran program IMAS (Image Streaming) sebab pembelajaran jenis ini selain dapat membangkitkan minat dan motivasi siswa juga dapat menjadikan perbedaan setiap individu menjadi bahan pembelajaran, bukan menjadi masalah.

Pembelajaran kooperatif juga diaplikasikan untuk semua jenis kelas, termasuk kelas-kelas yang khusus untuk anak-anak berbakat, kelas pendidikan khusus, dan bahkan untuk kelas dengan tingkat kecerdasan rata-rata, dan khususnya sangat diperlukan dalam kelas heterogen dengan berbagai tingkat kemampuan. Pembelajaran kooperatif juga dapat mengembangkan hubungan antar kelompok, penerimaan terhadap teman sekelas yang lemah dalam bidang akademik. Oleh karena itu, siswa yang lemah bidang akademiknya dapat memberikan sumbangsiterhadap timnya. Pembelajaran kooperatif ini dapat pula menumbuhkan kesadaran bahwa para siswa perlu belajar untuk berpikir, menyelesaikan masalah, mengintegrasikan serta mengaplikasikan kemampuan dan pengetahuan mereka.

\section{Metode Penelitian}

\section{Jenis Penelitian}

Jenis penelitian ini adalah penelitian tindakan kelas (Classroom Action Research) karena penelitian ini sifatnya menemukan bentuk pengajaran di kelas yang sesuai dengan permasalahan yang dihadapi secara lokal. Adapun pelaksanaannya melalui dua siklus yang terdiri dari empat tahap yaitu perencanaan, pelaksanaan tindakan, observasi dan evaluasi, serta refleksi.

Penelitian ini termasuk kualitatif dan kuantitatif, yang dimaksud dengan penelitian kualitatif yaitu prosedur penelitian tersebut menghasilkan data deskripsi tentang katakata tertulis. Sedangkan penelitian ini termasuk kualitatif karena lebih sistematis, terencana, terstruktur, jelas dari awal hingga akhir, dan juga penelitian yang banyak menuntut penggunaan angka, mulai dari pengumpulan data, penafsiran terhadap data tersebut, serta penampilan dari hasilnya.

\section{Data dan Sumber Data}

1) Data

Data dalam penelitian ini adalah penerapan model pembelajaran kooperatif tipe pengaliran program IMAS (Iamge Streaming) pada mata pelajaran bahasa Indonesia dalam menulis karangan naratif, aktifitas siswa, dan hasil belajar siswa.

2) Sumber Data

Sumber data dalam penelitian ini adalah siswa kelas X.5 SMA Negeri 1 Polongbangkeng Utara dengan jumlah siswa 29 orang siswa tahun pelajaran 2014-2015 yang berjumlah 29 orang. Penelitian ini dilakukan di SMA Negeri 1 Polongbangkeng Utara beralamat di Jl. Hj. Manila Dg. Pati Palleko Kabupaten Takalar.

Adapun gambaran kegiatan yang dilakukan masing-masing siklus penelitian sebagai berikut:

\section{Teknik Pengumpulan Data}

Pengumpulan data dalam penelitian ini menggunakan teknik 1) Pengamatan atau Observasi adalah proses pengambilan data dalam penelitian di mana peneliti atau pengamat melihat situasi penelitian (Susetyo, 2005: 1). Observasi dalam penelitian ini dilaksanakan dalam dua tahap, yakni observasi awal dan observasi pelaksanaan tindakan. Observasi awal dilaksanakan pada tahap studi pendahuluan untuk mengidentifikasi permasalahan sebelum dilaksanakan tindakan bertujuan untuk merekam aktivitas guru dan siswa dalam pembelajaran menulis karangan naratif. Peneliti menggunakan lembar observasi atau catatan lapangan untuk mencatat setiap aktivitas guru dan siswa selama proses pembelajaran berlangsung, 2) Analisis 
Dokumen dilaksanakan untuk mengetahui kemampuan siswa dalam menulis karangan naratif. Dokumen yang digunakan adalah hasil karya siswa yang berupa karangan naratif. Analisis dokumen juga dilaksanakan untuk mengetahui ada tidaknya peningkatan kemampuan siswa dalam menulis karangan naratif setelah diberi tindakan dengan menggunakan model pembelajaran kooperatif tipe pengaliran program IMAS (Image Streaming).

\section{Teknik Analisis Data}

Analisis data dalam penelitian ini dilaksanakan dengan langkah-langkah sebagai berikut:

1. Menelaah data terkumpul.

2. Mereduksi data, yakni menyeleksi, memfokuskan, dan menyederhanakan semua data yang diperoleh.

3. Menyimpulkan data yang telah direduksi dan disajikan secara naratif.

Untuk menganalisis kemampuan siswa dalam menulis karangan naratif, dilaksanakan penilaian terhadap karangan naratif siswa. Penilaian dilakukan dengan memberikan skor terlebih dahulu terhadap karngan naratif siswa, sesuai dengan indikator yang telah ditentukan dalam pedoman penyekoran.

\section{Hasil Penelitian}

1. Analisis Aktivitas Belajar Siswa Siklus I

a. Perencanaan

Pada tahap perencanaan ini peneliti mulai merencanakan apa yang dilaksanakan pada siklus 1, adapun tahap perencanaan itu adalah menelaah kurikulum SMA Negeri 1
Polongbangkeng Utara Semester 1 khususnya pokok bahasan menulis paragraf naratif, Membuat perangkat pembelajaran yang berupa RPP, membuat pedoman observasi untuk merekam proses pembelajaran yang akan dilaksanakan, membuat alat evaluasi berupa tes ditiap akhir siklus untuk mengetahui tingkat penguasaan siswa untuk materi menulis paragraf naratif, mengembangkan model pembelajaran dalam rangka optimalisasi pengajaran, menjadwalkan pelaksanaan kegiatan siklus 1 ditetapkan 4 kali pertemuan. Tiap pertemuan dilaksanakan 2 x 45 menit atau 2 jam pelajaran.

b. Pelaksanaan Tindakan

Tahap pelaksanaan pada Siklus 1 sebanyak 3 kali pertemuan diimplementasikan berdasarkan RPP yang telah disusun berdasarkan model pembelajaran kooperatif tipe pengaliran program IMAS (Image Streaming).

Hasil evaluasi tersebut kemudian dianalisis dan direfleksi. Berdasarkan hasil evaluasi Siklus I.

c. Observasi

Pembelajaran menulis paragraf naratif dengan menggunakan model pembelajaran kooperatif tipe pengaliran program IMAS (Image Streaming) ini, siswa sangat antusias.

Data tentang aktivitas siswa dalam mengikuti pembelajaran bahasa Indonesia diperoleh melalui lembar observasi. Adapun deskriptif tentang aktivitas siswa selama mengikuti proses pembelajaran pada Siklus I ditunjukkan dalam tabel 4.1 berikut.

Tabel 4. 1 Hasil observasi aktivitas siswa selama mengikuti Pembelajaran Siklus I

\begin{tabular}{ccccc|cc}
\hline & & & & & & \\
No Komponen yang diamati & \multicolumn{3}{c|}{ Pertemuan } & Persent \\
\cline { 3 - 4 } & I & II & III & IV & rata & $\begin{array}{c}\text { ase } \\
\text { (\%) }\end{array}$ \\
\hline
\end{tabular}




\begin{tabular}{|c|c|c|c|c|c|c|c|}
\hline 1 & $\begin{array}{l}\text { Siswa yang hadir pada saat } \\
\text { pembelajaran }\end{array}$ & 28 & 29 & 29 & & 28,7 & 98,97 \\
\hline 2 & $\begin{array}{l}\text { Siswa yang } \\
\text { memperhatikan materi } \\
\text { pelajaran yang sedang } \\
\text { berlangsung }\end{array}$ & 20 & 23 & 26 & $\mathbf{T}$ & 23 & 79,31 \\
\hline 3 & $\begin{array}{l}\text { Siswa yang aktif bertanya } \\
\text { tentang materi yang belum } \\
\text { di pahami }\end{array}$ & 3 & 5 & 7 & $\mathbf{S}$ & 5 & 17,24 \\
\hline 4 & $\begin{array}{l}\text { Siswa yang mengerjakan } \\
\text { tugas latihan yang } \\
\text { diberikan dengan } \\
\text { menggunakan Model } \\
\text { Pembelajaran IMAS } \\
\text { (Image Streaming) }\end{array}$ & 29 & 29 & 29 & $\begin{array}{l}\mathbf{S} \\
\mathbf{I} \\
\mathbf{K} \\
\mathbf{L}\end{array}$ & 29 & 100 \\
\hline 5 & $\begin{array}{l}\text { Siswa yang mencatat } \\
\text { materi pelajaran yang } \\
\text { diberikan }\end{array}$ & 29 & 29 & 29 & $\begin{array}{l}\mathbf{U} \\
\mathbf{S}\end{array}$ & 29 & 100 \\
\hline 6 & $\begin{array}{l}\text { Siswa yang menyimpulkan } \\
\text { materi pelajaran }\end{array}$ & 14 & 16 & 20 & I & 16,7 & 57,59 \\
\hline 7 & $\begin{array}{l}\text { Siswa yang menyelesaikan } \\
\text { tugas tepat waktu }\end{array}$ & 23 & 25 & 28 & & 25,3 & 87,24 \\
\hline
\end{tabular}

Pada Tabel 4.1, diperoleh bahwa pada siklus I dari 29 siswa, siswa yang hadir pada saat pembelajaran sebanyak $100 \%$, siswa yang memperhatikan materi pelajaran yang sedang berlangsung 79,31\% siswa yang aktif bertanya tentang materi yang belum dipahami $17,24 \%$ siswa yang mengerjakan tugas latihan yang diberikan $100 \%$, siswa yang mencatat materi pelajaran yang diberikan $100 \%$, siswa yang menyimpulkan materi pelajaran $57,59 \%$ siswa yang menyelesaikan tugas tepat waktu $87,24 \%$. Adapun data hasil belajar keterampilan menulis paragraf naratif pada siklus 1 dapat dilihat pada tabel 4.2 berikut:

Tabel 4.2 Statistik hasil belajar keterampilan menulis karangan naratif siswa setelah proses pembelajaran pada siklus I.

\begin{tabular}{|c|c|c|}
\hline No & 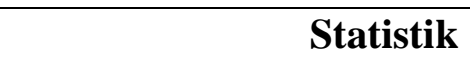 & Nilai Statistik \\
\hline & Subyek & 29 \\
\hline 2. & Rata-rata & 69,59 \\
\hline 3. & Skor Maksimum & 85 \\
\hline
\end{tabular}




$\begin{array}{clc}4 . & \text { Skor Minimum } & 50 \\ 5 & \text { Jumlah Siswa yang Tuntas } & 13 \\ 6 . . & \text { Jumlah Siswa yang tidak Tuntas } & 16\end{array}$

Pada tabel 4.2 menunjukkan bahwa nilai rata-rata hasil belajar keterampilan menulis paragraf naratif setelah proses pembelajaran pada siklus I adalah 69,59\% dari skor ideal 100. Banyaknya siswa yang tuntas 13 orang $(44,82 \%)$. Dari hasil ini dapat diketahui bahwa hasil belajar keterampilan menulis belum mencapai standar ketentuan klasikal yaitu $75 \%$ siswa yang memperoleh skor nilai 70 dari skor ideal.Jika nilai hasil belajar siswa setelah proses belajar mengajar menulis paragraf naratif dengan menggunakan model pembelajaran kooperatif tipe pengaliran program IMAS (image streaming) pada siklus I dikelompokkan kedalam lima kategori, maka diperoleh distribusi frekuensi dan persentase nilai seperti yang ditunjukkan pada tabel 4.3 berikut:

Tabel 4.3 Distribusi frekuensi, dan persentase hasil belajar keterampilan menulis paragraf naratif pada siklus I:

\begin{tabular}{llcc}
\hline \multicolumn{1}{c}{ Nilai } & Kategori & Frekuensi & Presentase\% \\
\hline$<60$ & Sangat Rendah & 5 & 17,24 \\
\hline $61-70$ & Rendah & 11 & 37,93 \\
\hline $71-80$ & Sedang & 12 & 41,37 \\
\hline $81-90$ & Tinggi & 1 & 3,44 \\
\hline $91-100$ & Sangat Tinggi & 0 & 0 \\
\hline Jumlah & & 29 & 99,98 \\
\hline
\end{tabular}

Tabel 4.3 menunjukkan bahwa 5 orang $(17,24 \%)$ siswa memiliki skor keterampilan menulis paragraf naratif dalam kategori sangat rendah, 11 orang $(37,93 \%)$ berada dalam kategori rendah, 12 orang $(41,37 \%)$ siswa yang memiliki skor yang

Tabel 4.4 deskripsi ketuntasan menulis paragraf naratif siswa kelas X.5 SMA Negeri

\begin{tabular}{ccccc}
\multicolumn{6}{c}{ I Polut pada siklus I. } & Kategori & Frekuensi & Presentase \% \\
\hline No & Nilai & & 16 & 55,17 \\
\hline 1 & $0-74$ & Tidak tuntas & 13 & 44,82 \\
\hline 2 & $75-100$ & Tuntas & & \\
\hline
\end{tabular}

berada dalam kategori sedang, 1 orang $(3,44 \%)$ berada dalam kategori tinggi dan tak seorangpun siswa yang memiliki skor keterampilan menulis paragraf naratif berada dalam kategori sangat tinggi. 
Tabel 4.4 menunjukkan bahwa banyaknya siswa yang tidak tuntas adalah 16 orang $(55,17 \%)$, sedangkan yang tuntas adalah 13 orang $(44,82 \%)$, jika nilai rata-rata hasil belajar siswa setelah diterapkan proses pembelajaran (nilai siklus I) yaitu 69,59 dihubungkan dengan kategori di atas maka nilai rata-rata hasil belajar siswa berada dalam kategori rendah. Hal ini berarti bahwa tingkat hasil belajar keterampilan menulis paragraf naratif siswa kelas X.5 SMA Negeri I Polut setelah proses pembelajaran pada siklus I berada dalam kategori rendah.

d. Refleksi

Pada pertemuan-pertemuan awal pelaksanaan Siklus I semangat dan keaktifan siswa menyelesaikan tugas yang diberikan mengalami perubahan dibanding dengan sebelum pelaksanaan tindakan. Pada umumnya siswa hanya menulis paragraf naratif yang kurang lengkap. Adapun beberapa siswa yang menulis paragraf naratif melalui model pembelajaran kooperatif tipe pengaliran program IMAS (image streaming) yang hampir lengkap namun cara penyusunan kalimat dan ejaannya masih kurang diperhatikan. Namun, pada umumnya siswa tersebut hanya siswa yang memperoleh nilai yang baik pada tugas-tugas sebelumnya, dibandingkan siswa yang lain.

2. Analisis Aktifitas Belajar Siswa Siklus II a. Perencanaan

Penelitian tindakan kelas yang berlangsung pada Siklus II sebagian besar sama dengan kegiatan pada Siklus I.
Pembelajaran pada Siklus II merupakan tindakan lanjut pelaksanaan Siklus I, diperoleh suatu gambaran tindakan yang akan dilaksanakan pada Siklus II ini, sebagai perbaikan atas kegiatan yang telah dilakukan pada Siklus I, adapun tindakan yang dilaksanakan yaitu siswa yang berada pada kategori rendah diberikan bimbingan khusus, lebih mempererat pengawasan kepada siswa yang sering melakukan kegiatan yang kurang positif di dalam kelas, Guru lebih memberikan motivasi dan penghargaan kepada siswa agar lebih semangat dalam mengikuti proses pembelajaran.

b. Pelaksanaan Tindakan

Tahap tindakan pada Siklus II selama 4 kali pertemuan diimplementasikan berdasarkan RPP yang telah disusun berdasarkan model pembelajaran kooperatif tipe program pengaliran IMAS (image streaming), dengan membenahi hal-hal yang dianggap masih kurang pada Siklus I yang dapat membantu siswa dalam menulis paragraf naratif. Hasil dari evaluasi tersebut kemudian dianalisis dan direfleksi. Berdasarkan hasil evaluasi Siklus I, terlihat keadaan kelas mengalami peningkatan.

c. Observasi dan Evaluasi

Data tentang aktivitas siswa dalam mengikuti pembelajaran bahasa Indonesia diperoleh melalui lembar observasi. Adapun deskriptif tentang aktivitas siswa selama mengikuti proses pembelajaran pada Siklus I ditunjukkan dalam tabel 4.5 berikut;

Tabel 4.5 Hasil observasi aktifitas siswa selama mengikuti pembelajaran Siklus II

\begin{tabular}{llllll|cc} 
No Komponen yang diamati & \multicolumn{3}{c|}{ Pertemuan } & & Rata- & Persenta \\
\cline { 2 - 5 } & & I & II & III & IV & rata & se (\%)
\end{tabular}




\begin{tabular}{|c|c|c|c|c|c|c|c|}
\hline 1 & $\begin{array}{l}\text { Siswa yang hadir pada saat } \\
\text { pembelajaran }\end{array}$ & 29 & 29 & 29 & \multirow{3}{*}{$\begin{array}{l}\mathbf{T} \\
\mathbf{E} \\
\mathbf{S}\end{array}$} & \multirow[b]{2}{*}{$\begin{array}{l}\mathbf{T} \\
\mathbf{E} \\
\mathbf{S}\end{array}$} & 100 \\
\hline 2 & $\begin{array}{l}\text { Siswa yang } \\
\text { memperhatikan materi } \\
\text { pelajaran yang sedang } \\
\text { berlangsung }\end{array}$ & 26 & 27 & 29 & & & 94,13 \\
\hline 3 & $\begin{array}{l}\text { Siswa yang aktif bertanya } \\
\text { tentang materi yang belum } \\
\text { di pahami }\end{array}$ & 4 & 8 & 10 & & 7,3 & 25,17 \\
\hline 4 & $\begin{array}{l}\text { Siswa yang mengerjakan } \\
\text { tugas latihan yang } \\
\text { diberikan dengan } \\
\text { menggunakan Model } \\
\text { Pembelajaran IMAS } \\
\text { (Image Streaming) }\end{array}$ & 29 & 29 & 29 & $\begin{array}{l}\mathbf{S} \\
\mathbf{I} \\
\mathbf{K} \\
\mathbf{L}\end{array}$ & 29 & 100 \\
\hline 5 & $\begin{array}{l}\text { Siswa yang mencatat } \\
\text { materi pelajaran yang } \\
\text { diberikan }\end{array}$ & 29 & 29 & 29 & $\begin{array}{l}\mathbf{U} \\
\mathbf{S}\end{array}$ & 29 & 100 \\
\hline 6 & $\begin{array}{l}\text { Siswa yang menyimpulkan } \\
\text { materi pelajaran }\end{array}$ & 16 & 20 & 23 & II & 19,7 & 67,93 \\
\hline 7 & $\begin{array}{l}\text { Siswa yang menyelesaikan } \\
\text { tugas tepat waktu }\end{array}$ & 29 & 29 & 29 & & 29 & 100 \\
\hline
\end{tabular}

Pada tabel 4.5, diperoleh bahwa pada Silkus II dari 29 siswa, siswa yang hadir pada saat pembelajaran sebanyak $100 \%$, siswa yang memperhatikan materi pelajaran yang sedang berlangsung $94,13 \%$, siswa yang aktif bertanya tentang materi yang belum dipahami $25,17 \%$, siswa yang mengerjakan tugas latihan yang diberikan $100 \%$, siswa yang mencatat materi pelajaran yang diberikan $100 \%$, siswa yang menyimpulkan matei pelajaran $67,93 \%$, siswa yang menyelesaikan tugas tepat waktu $100 \%$.

Adapun data hasil belajar keterampilan menulis paragraf naratif Siklus II dapat dilihat pada tabel 4.6 berikut;

Tabel 4.6 Statistik hasil belajar keterampilan menulis karangan naratif siswa setelah proses pembelajaran pada siklus II.

\begin{tabular}{clc}
\hline No & \multicolumn{1}{c}{ Statistik } & Nilai Statistik \\
\hline 1. & Subyek & 29 \\
2. & Rata-rata & 83,13 \\
3. & Skor Maksimum & 95 \\
4. & Skor Minimum & 75 \\
5 & Jumlah Siswa yang Tuntas & 29 \\
$6 .$. & Jumlah Siswa yang tidak Tuntas & 0 \\
\hline
\end{tabular}


Pada tabel 4.6 menunjukkan bahwa nilai rata-rata hasil belajar keterampilan menulis paragraf naratif setelah proses pembelajaran pada siklus II adalah 83,13 dari skor ideal 100. Banyaknya siswa yang tuntas 29 orang dengan persentase $100 \%$. Dari hasil ini dapat diketahui bahwa hasil belajar keterampilan menulis sudah mencapai standar ketentuan klasikal yaitu $85 \%$ siswa yang memperoleh skor nilai 75 dari skor ideal. Jika nilai hasil belajar keterampilan menulis paragraf naratif dengan menggunakan model pembelajaran kooperatif tipe pengaliran program IMAS (image streaming) pada siklus II dikelompokkan kedalam lima kategori, maka diperoleh distribusi frekuensi dan persentase nilai seperti yang ditunjukkan pada tabel 4.7 berikut:

Tabel 4.7 Distribusi frekuensi, dan persentase hasil belajar keterampilan menulis paragraf naratif pada siklus II:

\begin{tabular}{llcc}
\hline \multicolumn{1}{c}{ Nilai } & Kategori & Frekuensi & Presentase \% \\
\hline$<60$ & Sangat Rendah & 0 & 0 \\
\hline $61-70$ & Rendah & 0 & 0 \\
\hline $71-80$ & Sedang & 15 & 51,72 \\
\hline $81-90$ & Tinggi & 10 & 34,48 \\
\hline $91-100$ & Sangat Tinggi & 4 & 13,79 \\
\hline Jumlah & & 29 & 99,99 \\
\hline
\end{tabular}

Tabel 4.7 menunjukkan bahwa 15 yang memiliki skor yang berada dalam orang $(51,72 \%)$ siswa memiliki skor kategori sangat tinggi dan tak seorangpun keterampilan menulis paragraf naratif dalam siswa yang memiliki skor keterampilan kategori sedang, 10 orang $(34,48 \%)$ berada menulis paragraf naratif berada dalam dalam kategori tinggi, 4 orang $(13,79)$ siswa kategorirendah dan sangat rendah.

Tabel 4.8 deskripsi ketuntasan menulis paragraf naratif siswa kelas X.5 SMA Negeri I Polut pada siklus II.

\begin{tabular}{ccccc}
\hline No & Nilai & Kategori & Frekuensi & Presentase \% \\
\hline 1. & $0-74$ & Tidak tuntas & 0 & 0 \\
\hline 2. & $75-100$ & Tuntas & 29 & 100 \\
\hline & Jumlah & & 29 & 0 \\
\hline
\end{tabular}


Tabel 4.8 menunjukkan bahwa banyaknya siswa yang tuntas adalah 29 orang $(100 \%)$. Jika nilai rata-rata hasil belajar keterampilan menulis paragraf naratif pada Siklus II yaitu 83,13 dihubungkan dengan kategori di atas, maka nilai rata-rata hasil keterampilan menulis karangan naratif sudah berada dalam kategori tinggi. Hal ini menunjukkan bahwa tingkat hasil belajar keterampilan menulis paragraf naratif siswa kelas X.5 SMA Negeri I Polut mengalami peningkatan sebelumnya berada dalam kategori rendah menjadi kategori tinggi. Secara rinci peningkatan keterampilan menulis karangan naratif dengan menggunakan model pembelajaran kooperatif tipe pengaliran program IMAS (image streaming) pada siswa kelas X.5 SMA Negeri I Polut dari siklus I dan siklus II dapat dilihat dalam tabel 4.9 berikut ini:

Tabel 4.9 Perkembangan frekuensi hasil belajar menulis deskripsi paragraf naratif siswa kelas X.5 SMA Negeri I Polut pada siklus I dan siklus II

\begin{tabular}{lllc|c}
\hline No & Interval Nilai & \multicolumn{1}{c}{ Kategori } & \multicolumn{2}{c}{ Siklus/Frekuensi } \\
\cline { 3 - 5 } & & & I & II \\
\hline 1. & $<60$ & Sangat rendah & 5 & 0 \\
2. & $61-70$ & Rendah & 11 & 0 \\
3. & $71-80$ & Sedang & 12 & 15 \\
4. & $81-90$ & Tinggi & 1 & 10 \\
5. & $90-100$ & Sangat tinggi & 0 & 4 \\
\hline & Jumlah siswa & & 29 & 29 \\
\hline & Jumlah nilai & & 2018 & 2411 \\
\hline & Rata-rata & 69,59 & 83,13 \\
\hline
\end{tabular}

Dari tabel di atas dapat dilihat bahwa nilai rata-rata perolehan siswa setelah dua kali pelaksanaan tes akhir siklus ternyata hasil belajar keterampilan menulis paragraf naratif siswa kelas X.5 SMA Negeri I Polut mengalami peningkatan.

d. Refleksi Siklus II

Pada Siklus II perhatian dan keaktifan siswa semakin memperlihatkan kemajuan. Hal ini terjadi karena seringnya siswa mengajukan pertanyaan apabila masih ada hal-hal yang belum dipahami, siswa cukup antusias dalam menulis karangan naratif dengan menggunakan pilihan kata dan kalimat yang tepat dan benar sesuai EYD dan siswa juga mulai terbiasa dengan penerapan model pembelajaran kooperatif tipe pengaliran program IMAS (image streaming).

\section{SIMPULAN}

Berdasarkan rumusan masalah dari hasil penelitian serta pembahasan yang telah diuraikan di atas, maka peneliti dapat membuat kesimpulan sebagai berikut;

Keterampilan menulis karangan naratif melalui implementasi model pembelajaran kooperatif tipe pengaliran program IMAS (Image Streaming) pada 
siswa kelas X.5 SMA Negeri I Polut Kabupaten Takalar menunjukkan adanya peningkatan aktivitas siswa dalam proses pembelajaran menulis karangan naratif berdasarkan hasil observasi yang telah dilakukan, peningkatan ini tidak hanya pada hasil belajar siswa tetapi terbukti adanya perubahan perilaku negatif siswa menjadi perilaku positif.

Keterampilan menulis karangan naratif setelah melihat hasil penelitian menunjukkan adanya peningkatan hasil belajar siswa di siklus I ke siklus II. Skor ratarata siklus I 69,59 dengan ketuntasan klasikal 13 orang $(44,82 \%)$ tuntas, berada pada kategori rendah dan meningkat pada siklus II 83,13 dengan ketuntasan klasikal 29 orang (100\%). Hal ini didukung pula oleh peningkatan aktifitas siswa dalam proses pembelajaran menulis paragraf naratif dengan menggunakan model pembelajaran kooperatif tipe pengaliran program IMAS (image streaming) mengalami peningkatan.

Ini berarti penerapan model pembelajaran kooperatif tipe pengaliran program IMAS (image streaming) dalam pembelajaran bahasa Indonesia dapat meningkatkan kemampuan menulis karangan naratif pada siswa kelas X.5 SMA Negeri I Polut Kabupaten Takalar.

\section{DAFTAR PUSTAKA}

Akhadiah, S., Arsjad, M. G. \& Ridwan, S. H. 1988. Pembinaan Kemampuan Menulis Bahasa Indonesia. Jakarta: Erlangga.

Arikunto. 2007, Suharsimi; Suhardjono; Dan Supardi. 2007. Penelitian Tindakan Kela. Jakarta: Bumi Aksara.

Arikunto, Suharsimi. 2008. Prosedur Penelitian: Suatu Pendekatan Praktek. Jakarta: Rineka Cipta.

Gie, The Liang. 2002. Terampil Mengarang. Yogyakarta: Andi.
Http://Didaytea.Blogspot.Com/2006/10/Ima

ge-Streaming.Html.Diakses

Tanggal 12 Februari 2015.

Http://Library.Um.Ac.Id/Ptk/Index.Php?Mo $\mathrm{d}=$ Detail\& $\mathrm{Id}=48592$. Diakses

Tanggal 22 Februari 2015.

Kurniawan, Khaeruddin. 2007. Model Pengajaran Menulis Bahasa Indonesia Bagi Penutur Asing Tingkat Lanjut, (Online), (Http: //Www.Laft.Edu?Kipbipa/Papers/K haerudinkurniawan.Doc,Diakses

Tanggal 12 Februari 2015).

Munirah. 2007. Dasar Keterampilan Menulis. Makassar: Fakultas Keguruan Dan Ilmu Pendidikan Universitas Muhammadiyah Makassar.

Munirah. 2013. Pengembangan Keterampilan Menulis. Makassar: Fakultas Keguruan Dan Ilmu Pendidikan Universitas

Muhammadiyah Makassar.

Nismawati. 2011. Kemampuan Siswa Kelas

Vii.2 Smp Negeri 1 Parangloe Kabupaten Gowa Dalam Menyusun Kalimat Majemuk. Makassar: Fakultas Keguruan Dan Ilmu Pendidikan Universitas Muhammadiyah Makassar.

Pribadi, Benny A. 2009. Model Desain Sistem Pembelajaran. Jakarta: Dian Rakyat.

Rahim, A. Rahman., \& Paelori, Thamrin. (2013). Seluk Beluk Bahasa Dan Sastra Indonesia. Surakarta: Romiz Aisy.

Susetyo, Budi. 2005. Jenis Alat Pengumpulan Data, (Online), (Http://Www.Ditplb.Or.Id/New/Ind ex.Php?Menu=Profile \&Pro=145,Di akses Tanggal 12 Maret 2015. 
Tarigan, Henry Guntur. 1982. Menulis Sebagai Suatu Keterampilan Berbahasa. Bandung: Angkasa.

Taniredja, Tukiran, Dkk. 2013. Penelitian Tindakan Kelas Untuk Pengembangan Profesi Guru Praktik, Praktis, Dan Mudah. Bandung: Alfabeta.

Wenger, Win. 2004. Beyond Teaching And Learning Memadukan Quantum Teaching Dan Learning. (Terjemahan). Bandung: Nuansa. 